\title{
Research on the Application of Management Accounting on Enterprise Management
}

\author{
Yi Sun \\ Inner Mongolia University of Science \&Technology, Baotou, Inner Mongolia, 014000
}

Keywords: enterprise management; management accounting; application research

\begin{abstract}
With the development of China's economy and the progress of society, Chinese enterprises have ushered in new opportunities for development. More and more enterprises are gradually moving towards the world and are in line with international standards. Although enterprise management accounting has a short history in the development of Chinese enterprises, the role of enterprise management in business management has been highlighted in recent years. Especially since the economic globalization, Chinese government and enterprises have been aware of it, actively respond to the continuous application of enterprise management accounting in business management, and have continued to achieve remarkable results. However, due to the relatively late establishment of China's accounting system compared with Western countries, there are still some problems in the practical application of enterprise management accounting. This paper makes a brief discussion on the application of enterprise management accounting in enterprise development and management, and hopes to play a certain role in helping the development of Chinese enterprises.
\end{abstract}

\section{Introduction}

Management accounting has a big difference from financial accounting. Management accounting usually takes the company's fund movement as the object of investigation. Its purpose is to effectively improve the company's economic efficiency, and to provide scientific decision-making basis for business management. Management accounting plays an important role in the business management decision-making and performance evaluation. However, the current management accounting has not yet been widely implemented in the business management. Therefore, it is necessary to actively explore ways to strengthen the application of management accounting in business management.

\section{The Role of Management Accounting in Business Management}

In business management, management accounting can provide various management information for enterprises. At present, the business management work needs to deeply understand and effectively grasp all kinds of information such as the financial cost status of the enterprise, the production and operation status of the enterprise, and the related management work within the enterprise. On this basis, scientific planning and effective control of the business management are carried out. Management accounting has a variety of technical working methods, which can achieve multi-channel collection and effective processing of all kinds of information related to business management, and form corresponding data information to effectively meet the needs of business management.

In enterprise management, management accounting can provide management decision basis for enterprises. Enterprises to make management decisions, on the one hand to collect and obtain all kinds of management information in a timely manner, on the one hand we must carry out scientific processing and collation in order to form the relevant basis for management decisions. Management accounting work through the daily management of the company's participation in the management, can quickly and easily access to all types of management information, and consciously convert all types of management information into scientific information and data, and then provide scientific 
and rational management decision-making basis.

In enterprise management, management accounting can provide scientific performance assessment for enterprises. In order to effectively accomplish the intended objectives of business management, the company must strengthen the tracking and control of daily operations and management activities. At the same time, it must conduct detailed records of the actual work of the company's various departments and staff to prepare for performance evaluation. Management accounting work can help companies establish and improve the performance appraisal and control system for various departments and employees, and help to formulate scientific and reasonable performance appraisal measures. Therefore, management accounting can provide enterprises with scientific performance appraisal. At the same time, the management accounting can achieve the immediate mastery of the completion progress of the company's business management goals, and conduct scientific evaluation of the company's work performance in various departments, thereby effectively improving the company's operational management efficiency and decision-making level.

\section{Development of Management Accounting in Business Management}

The relationship between corporate management accounting theory and actual corporate management accounting is not close enough. The earliest accounting system was established and implemented by Western countries. The establishment of China's accounting system is mainly to learn and learn from Western countries. Although our country has gone through years of exploration, hard work, and innovation in the theory and practice of enterprise management accounting, China's corporate accounting theory is still not very mature and its application in actual business operations is less than expected. The research and exploration of enterprise management accounting theory in China is mainly based on the introduction and introduction of the latest western research theories. However, due to the differences in the economic development systems, backgrounds, and levels of Chinese and foreign companies, the advanced Western theories have appeared to be applied in China's enterprise management. The dissatisfaction of land and water has hindered the popularization of enterprise management accounting theory in business operations.

Enterprise management accounting lacks sufficient attention in the business management. The attention of the enterprise managers is relatively low, and the relatively weak management accounting consciousness seriously hampers the application of enterprise management accounting in the business operations. Corporate managers often think of accounting as simple accounting records, verifications, audits, and accounting reports. As for the management of accounting decisions, it depends on the leaders of the company. Due to the one-sidedness of corporate leaders' understanding of corporate management accounting, the application of corporate management accounting in corporate operations has not been effectively developed.

Our country lacks a good social environment. A good social environment is an external factor in the application and development of corporate management accounting in corporate operations. Although China's market economic system has been established and implemented with proud results, at present, China's corporate management accounting system needs continuous construction. And perfect.

\section{Applied Strategies of Management Accounting in Business Operations}

Strengthen the combination of enterprise management accounting theory and practice. Although the study of China's enterprise management accounting theory is not deep enough, the theory of management accounting is the basis of practice. We must combine theoretical research with China's market economic system, boldly innovate in enterprise management accounting boldly, and establish characteristics of socialism with Chinese characteristics. Corporate management accounting theory. Enterprises must base themselves on practice, link the management accounting theory with the actual development of the enterprise, and then combine some management accounting theories to apply more successful cases in the business operations and synthesize it, and gradually promote the theory in the business operation, and gradually The theory penetrates into the 
daily work of the company and improves the economic efficiency and management of the company.

Enhance corporate management managers' understanding of management accounting. The ideology of business leaders determines the direction of development of the company as a whole, and it is necessary to constantly improve the understanding of corporate management decision makers in corporate management accounting so that they can recognize the value of corporate management accounting in business operations in order to face changes in the face of rapid changes. The market's time is calm, combined with the accounting information provided by the management accounting to make a scientific and rational choice, to ensure that the development of enterprises can adapt to market changes in a timely manner. A variety of means can be used to improve the understanding of management accounting by corporate management decision makers, such as the establishment of specialized open classes, corporate research, and corporate day-to-day publicity. Only by continuously improving the awareness of corporate management decision makers can we gradually promote the application of corporate management accounting in business operations, and help enterprises survive and develop.

Improve the overall quality of management accountants. First of all, when recruiting management accounting personnel, enterprises should select candidates with accounting qualification certificates to fundamentally improve the overall quality of management accounting personnel. Secondly, it is necessary to conduct regular professional training for management accountants. The speed of technology update is extremely fast. The staff must constantly learn and improve their professional knowledge. The company can regularly arrange management accounting personnel to attend classes, visit studies, and knowledge. Activities such as competitions improve the comprehensive ability of accountants. Finally, the performance of management accountants can be evaluated regularly and irregularly. The employees with outstanding performances are also criticized for some poorly performing employees, and the initiative and enthusiasm of management accountants are mobilized.

The main analysis methods of management accounting include cost behavior analysis and CVP analysis. The cost behavior method mainly deals with the demand problems in the cost control and planning work of the company's business process. This will help the company to grasp the relationship between the cost and the business volume quantitatively, so as to achieve the highest quality management. The CVP analysis method is a mathematical analysis method between the cost, the business volume, and the profit in the enterprise, thereby providing a reliable financial information for the accounting prediction and planning. Management accounting takes long-term, contingent management features to provide reliable and decision-making relevant information for business operations.

Strengthen the application of management accounting in business management, and improve the management accounting quality of enterprise accounting personnel. At present, accounting staff of most enterprises are relatively lack of theoretical knowledge and practical operating experience of management accounting. Therefore, it is necessary to strengthen pre-post training and on-the-job education for accounting practitioners in order to effectively improve the accounting quality of accounting practitioners. It is necessary to improve the teaching curriculum system of management accounting, adopt flexible and efficient teaching methods, provide detailed explanation training for accounting practitioners on theoretical knowledge of management accounting and practical application skills, and effectively improve the theoretical knowledge and practice of management accounting for accounting practitioners. Operational application capabilities. Enterprises should strengthen the post training for accounting personnel, enhance the accounting personnel's management accounting work level, and effectively play the role of management accounting for business management. To strengthen the use of management accounting in the management of enterprises, it is necessary to strengthen the study of management accounting application cases. The management of the company shall organize relevant management personnel and accounting staff to conduct research on the practical application cases of management accounting, conduct in-depth analysis and summary of the case experience of practical application of management accounting in the enterprise operation and management, and effectively obtain management accounting work. 
Practical experience and objective laws, comparing the current state of business management, combining the development goals of business management and the needs of enterprises, scientifically and rationally adjusting existing business management models of enterprises, improving the operational efficiency of business operations, and greatly increasing the economic efficiency of enterprises.

\section{Conclusion}

Management accounting plays an important role in strengthening internal management of enterprises and promoting the good development of enterprises. It is embodied in the fact that management accounting can provide various types of management information for enterprises, can provide management decision basis for enterprises, and can provide scientific performance assessment for enterprises. . Therefore, it is necessary to strengthen the management accountant's emphasis on management accounting, improve the accounting quality of enterprise accounting personnel, strengthen the study of management accounting application cases, and effectively strengthen the application of management accounting in enterprise management.

\section{References}

[1] Zhang Huapeng. Research on the Application of Management Accounting in Business Management [J]. Coal Economic Research, 2001, (4): 54-55.

[2] Zhang Xia. Application of Management Accounting in Business Management [J]. Business Economics, 2013, (22): 99-100.

[3] Tang Wei. On the Application of Management Accounting in China's Enterprise Management [J]. Market Research, 2012, (7): 59-61.

[4] Kang Hanzi. Problems and Countermeasures in the M\&A Financing of Chinese Enterprises [J]. China-ASEAN Expo, 2013, 21.

[5] Huang Yan. Existing problems and countermeasures in China's M\&A financing channels [J]. Hebei Corporation, 2013, 02. 